\title{
Institutional Innovation of Water Resources Management
}

\author{
Fang Liu*, Yinghui Miao \\ School of Public Administration \\ Shandong Normal University \\ Jinan, China \\ liufang7698@126.com
}

\author{
Wang Miao \\ College of Business Administration \\ Qilu University of Technology \\ Jinan, Chin
}

\begin{abstract}
The purpose of this paper is to solve the problems in water resources management in China: backward manage ment of water resources, lack of market manage ment and neglect of the implementation of water-saving policy. Through the overview of water resources management systems in the United States, Britain, France, Australia and Israel, it draws on the experience and compares the domestic situation so as to make the resolution of domestic problems more specific and characteristic. Adhere to the "people and water harmony" management philosophy, with the institutional innovation and ultimately to achieve the sustainable use of water resources protection. Innovation lies in the system as a starting point, seize the water resources administrative examination and approval system, water resources management responsibility and examination system, water rights system, water functional area supervision and management system to deepen the reform and achieve a virtuous circle of water resources.
\end{abstract}

Keywords-water management system; mechanism reform; virtuous circle; watershed management; institutional innovation

\section{INTRODUCTION}

Water is the most active and controlling factor in ecosystems. Human beings are born of water, live by the water and rejuvenate by water. Leaving water, it is not only difficult to sustain human society, but also no life can be extended. Therefore, water is the source of life, an irreplaceable natural resource and a country's economic resources, and it is an indispensable material basis for human society and productive activities. Water is a renewable natural resource that is continually restored through its own recycling process. Water resources, broadly speaking, refer to water in various forms (three-state of water: solid, liquid and gas) in the earth's hydrosphere. However, at present, human beings focus on the investigation and evaluation, development and utilization of water resources and more narrowly defined water resources. That is, it is generally referred to as participating in the water cycle in nature through the exchange of water between land and sea, and obtaining updated freshwater resources on the land year by year. Atmospheric precipitation is a supplementary source. The key to water management is to

This thesis is supported by Shandong Provincial Social Science Planning Research Project (17CLYJ10), Shandong Province Social Science Popularization Applied Research Project (2017-SKZZ-14), National Statistical Science Research Project (2017LY21), National Natural Science Foundation of China (71704097) and Special Research on Party History of Jinan Philosophy and Social Sciences Planning Project (JNSK18DS05) Funding. improve the utilization efficiency of water resources and protect the limited water resources by establishing an authoritative, efficient and coordinated integrated water management system.

\section{The Current Status of Water Resources MANAGEMENT SYSTEM}

\section{A. The Status Quo of Water Management Systems in Various Countries in the World}

1) Water Management in the United States

The United States is a federation of countries. Each state has a considerable legislative power, and the state government and the federal government is relatively loose. Therefore, according to the decree enacted by the U.S. Congress, water resources management is administered by the federal government agencies, the state government agencies and the local government agencies at three levels. The United States implements a management system based on state and local governments.

National administrative functions are mainly responsible for the national water resources planning, management, and coordination and water pollution control, to determine the overall management objectives and guidelines, the development of policies, regulations and standards. State and local administrations are responsible for the implementation of the overall national goals as well as the specific state and local indicators[1].There are also numerous water management agencies at the state level. In California, for example, there are California Water Resources Office, California Water Quality Authority, State Substances Control Authority, Metropolitan Water Authority, Southern California Water Recirculation Bureau and others. Mainly responsible for California's water supply and demand dispatch, major water conservancy project construction and operation and maintenance, water pollution control and diversion of water quality and safety.[2] Therefore, in the United States, there is no strict unified management of water resources. From the federal government and state governments to the counties and municipal governments, all establishments are based on the demand for water resources development and utilization. Nor are these institutions immutable, but rather adapt to the political, economic and cultural development. 


\section{2) Water Management in the Britain}

Water management in Britain has gone through two stages. Britain's water resources originally adopted a decentralized management approach. After the promulgation of the "Water Law" in 1973, unified management of watersheds began. After the revision of the "Water Law" in 1989, the nationalization of water services changed to privatization services. At present, the central government has basically formed a management system that integrates the unified management of water resources by watersheds and the privatization of water resources. [3] There are basically three characteristics: First, the state-level management and supervisory authorities make unified formulation and implementation of laws and regulations on water resources management, systems and policies; secondly, the establishment of a competent authority as a basic unit of river basins to supervise the implementation of water resources management policies; and thirdly, the specific affairs of water resources management such as water supply, drainage and sewage treatment shall be undertaken by private water companies.

\section{3) Water Management in France}

France is a democratic parliamentary state based on the separation of powers. The executive power is shared by the president and the prime minister and his government. The legislative power is controlled by the National Assembly and the Senate of the Parliament. The judicial power is exercised independently by the court.

Local administration in France is divided into three levels: Municipality, Department and Region. The municipality is France's smallest administrative classification body, governed by a city's parliament, with universal suffrage every 6 years. The mayors are created among parliamentarians and are mainly responsible for schools within the community and their transportation, urban planning, social activities, road systems, residents' sewerage and hygiene. There are 36,783 municipalities in France, large and small, and often form intermunicipal consortia to share resources. In the field of water, the French municipality is mainly responsible for the management of public drinking water and sanitation facilities and also has strong binding on water resources management, protection of aquatic environment and management planning of sub-basins. The France's department is governed by a departmental parliament, with parliamentary elections every 6 years. The departmental governor is the chief executive of the department, responsible for formulating, implementing, reviewing budgets and managing staff. France has a total of 101 departments (including 5 overseas departments) covering a wide range of jurisdictions, including social activities, university construction and operation, land remediation and school transport organizations. In the area of water, the French "department" plays an important role in rural development, financial support for drinking water supply and sanitation systems and the protection of the natural environment.

With the implementation of the Decentralization Laws of 1982, France's "Region" has become an autonomous local community organization. Members of the Region are elected by direct election every 6 years and the Speaker is elected. The Speaker of the Region manages the budget, staffing and application of policies, focusing mainly on economic activities, regional planning and vocational training. In France, there are 26 "major regions" (including 4 overseas "major regions"). In the water area, the major regions can make decisions through planning, financial support and nature protection and participate in the management of the water resources management system (basin committees, water agency boards and local water conservancy committees). And they play a role in planning documents application and contract signing.

France has a distributed (local decision-making given by the local service branch) and a decentralized structure (many rights are transferred by the state to local authorities). [4]The central government is in Paris, but the rights of national governments are decentralized at the "departmental" and "regional" levels, such as "the Prefect." The chiefs at the departmental and regional levels are the only state agencies within the territories under their administration, representing the government prime ministers and ministers. He or she is the local head of the decentralized public sector in the country, responsible for law and order, organizing different types of elections, emergency relief for disasters, ensuring law enforcement and acting as a consultant and supporter for local authorities. In the area of planning, he or she is also a negotiator for the development planning agreement between the government and the region. In the water area, the Chief Executive has also been appointed as a "watershed coordinator" in regions where the Basin Commission has offices, coordinating public affairs. Responsible for approving the main plan of basin water conservancy development and management drafted by the river basin committee and take the corresponding plan measures.

\section{4) Water Management in Australia}

Australia implements a water management and river basin management system. Water administration is centered on state governments, which ensures the implementation of water resources management policies, facilitates the dissemination and feedback of management information, and can formulate policies that are in line with actual conditions and avoid contradictions between multiple government agencies [5]. At the same time, adequate consultation mechanisms have enabled river basin management, which takes the diversion of water as its main activity, to operate. And he Murray-Darling Basin management provides a model for a unified management of water resources.

\section{5) Water Management in Israel}

Due to the grim situation of water resources, the Israeli government has gradually realized the importance and urgency of protecting water resources. At present, Israel adopts a comprehensive water resources management system to carry out sustainable management of water resources throughout the country. The Israeli government believes that IWRM contains five major elements: clear legal provisions, a sound government system, a comprehensive awareness of water conservation, efficient water use and advanced water technologies.

Here focuses on the government management system. Prior to 2006, Israel's water resources management authority distributed in various government departments. The Ministry of Infrastructure is responsible for the overall management of 
water resources; the Ministry of Agriculture is responsible for the allocation and pricing of agricultural water; the MEP is responsible for the control of water quality standards; the Ministry of Health is responsible for drinking water quality management; the Ministry of Finance is responsible for water pricing and water conservancy investment; and the Ministry of the Interior is responsible for the urban water supply[6]. In 2006, the Israeli government adjusted the functions of water resources management and allocated the unified decentralization of water resources management functions in different departments to the newly established Water and Sewage Resource Management Committee to manage the water resources and water circulation in the country. The committee is an interdepartmental agency with senior members of the Ministry of Finance, Ministry of Infrastructure, MEP and the Interior Ministry as commissioners, working under the leadership of the Water and Sewage Authority ("WSA"). The Water Board directs and oversees the operation of the WSA.

\section{6) Water Management in Japan}

In order to solve the severe water resources problem in Japan and meet the water demand brought by the economic development and the improvement of people's living standard, the Japanese government has established a set of management system with its own characteristics. Decades of practice have proved that the system as a whole is performing well and plays an important role in the effective management of Japan's water resources.

Japan's water resources management and implementation by a number of government departments and organizations to complete, and 'the management of water and use water separation and management of water resources by several heads are the most prominent features of Japan's water resources management system, and the role of the government in Japan's water resources management is very important, which is mainly manifested in three aspects: development of water resources development, Policies and overall plans for environmental protection; supervise water utilities, and maintain and manage water conservancy facilities; provide financial support for water resources management, of which the Central Government of Japan is responsible for the first and third aspects.The role of it is particularly noteworthy.

\section{7) Water Management in South Africa}

The South African government attaches great importance to the management of water resources. With the increasingly scarce water resources and the change of national political system, the guiding ideology, principles and management system of water resources management have undergone major changes.

South Africa's water management system is regulated by the "Water Law". The basic guiding principle of the new "W ater Law" is to realize the sustainable use of water resources and ensure fair and equitable use of water for all[7]. The following basic principles are set forth in the water resources management system: (1) The right to equal access to water; (2) Water resources is a public resource that must be used under the control of the state; (3) Have no ownership of water resources and only have the right to use; (4) There is no priority for the use of water resources in the vicinity of landowners, and the principle of river bank does not apply in that country; (5) Water management agencies should be as simple, effective and operational as possible; 6) Develop, allocate and manage available water resources should be borne by river basins and local governments to ensure stakeholder participation; (7) The units that benefit from the water resources management system should contribute to the maintenance of water resources and watersheds.

In accordance with this provision, South Africa has implemented an integrated management system. South Africa, initially through the establishment of a central agency of the Ministry of Water and Forestry, carried out vertical and unified management over the country's water resources. The Ministry of Water Resources and Forestry has offices in 9 provinces across the country. These offices are not under the provincial government but governed by the central government. They basically cover the responsibilities of water resources development, utilization, distribution and protection. In the meantime, the state has set up a water supply company to take charge of water supply in cities throughout the country.

Since 2001, the South African government has carried out further reforms on its water resources management system. The core of the reform has shifted from the central government's administration by administrative area to watershed management and absorbed the participation of water users.[8] The South African government plans to use 20 years to establish and improve 19 river basin agencies in 9 provinces throughout the country. Each agency establishes a watershed management committee with members of the Water and Forestry ministry, representatives of the municipalities and large water use representatives (such as mines) to manage water resources in the basin.

\section{B. Current status of China's water management system}

China's water resources management is mainly responsible for the Ministry of Water Resources. The Ministry of Water Resources is also responsible for the comprehensive management and development of major rivers and lakes in the country. Under the Ministry of Water Resources, the river basin management committees have been set up in the Yangtze River, the Yellow River, the Pearl River, the Songhua River, the Liao River, the Haihe River, the Huaihe River and the Lake Taihu respectively. Within the basin management committee, there is also a Water Resources Protection Bureau under the joint leadership of the Ministry of Water Resources and the State Environmental Protection Agency. All the provinces in China have a water conservancy agency within the government responsible for water resources management in the region.

The national system of water quality monitoring departments and the hydrological stations, water stations and rainfall stations all over the country, except for some of the Central Water Conservancy Department, mostly belong to the water conservancy departments of all local governments or subordinate to major river basin committees.

The environmental protection work in water resources is more centralized with the State Environmental Protection Administration in the organization and management. Therefore, 
the Water Resources Protection Bureau under the major river basin committees accepts the dual leadership of the Ministry of Water Resources and the State Environmental Protection Agency.

The scientific research department of water resources belongs to all competent departments, and only China Institute of Water Resources and Hydropower Research under the Ministry of Water Resources and the scientific research institutes of local water conservancy departments belong to the centralized water management system.

\section{Problems in Water Management in China}

\section{A. The Level of Water Resources Management is Backward}

Although the total amount of water resources in China is not small in all countries in the world, the degree of effective utilization of water resources in China is not ideal, and there is a great waste of both agricultural and industrial water. In some areas, water supplies are on the one hand, and water is wasted on the other. This shows that China's water resources management is still at a relatively backward level.

Agricultural water is the largest user of water, accounting for more than $80 \%$ of total water use. China's backward use of agricultural water, such as irrigation is basically a waste of flood irrigation, through which most of the water is evaporated. According to statistics, the average coefficient of canal utilization in China is 0.4-0.5; the coefficient of field water utilization in irrigation districts is 0.6-0.7, and the coefficient of irrigation and drainage is about 0.5. Compared with the industrialized water efficiency in developed countries, there is a big gap. At present, although the reuse rate of industrial water in urban areas in our country has been raised, it is still lower than the advanced countries.

\section{B. Did not Form A Market Management}

Water is a natural resource of practical value. Water after processing and delivery, is a commodity exactly.Therefore, water should be included in the commodity economy and comply with the law of value. The cost of water supply should include the costs of exploration, extraction, processing, transportation and maintenance of equipment, as well as management fees and taxes. The past practice of spending less money on water needs to be corrected. More importantly, water prices in China are currently low. The cost of urban industrial water accounts for only $0.1 \% \sim 1 \%$ of the cost, while the domestic water consumption accounts for only $0.5 \%$ $\sim 1 \%$ of the cost of living and the water fee for agricultural use is lower[9]. In 1985, the State Council promulgated the Measures on Accounting, Payment and Management of Water Conservancy Projects, and proposed ways of verifying water charges at cost. This is an attempt by the state to carry out water management through economic means. So far, the government still lacks the necessary economic means to manage water resources in terms of water prices and other aspects like taxation and investment. Water resources management has not been fully integrated into the market economy management.

\section{Ignored the Implementation of Water-saving Guidelines}

China's water consumption is rapidly increasing year by year. This rapid increase in water usage has caused the contradiction between water use and water supply in many cities and regions in China. To meet the socio-economic development and the water demand for residents' life, the state has basically implemented the parallel implementation of revenue-sharing and expenditure control policy. However, in fact, attention has been paid to developing new water sources and ignoring the implementation of water saving guidelines[10]. From top to bottom, there is a lack of awareness of the importance of water conservation, except for a few water-stressed areas in the country. Nationals use natural water as an invaluable commodity; large amounts of ineffective irrigation and leakage of agricultural irrigation water have not been improved for a long time; The use of pesticides and fertilizers led to the pollution of water sources; The cost of urban enterprises in the accounting for the share of small with high water consumption per unit of product. At present, the policies on the wastage of urban water are mostly directed against units rather than individuals, and this measure is basically ineffective. For a big country, if we do not implement the water-saving approach, it will be a big mistake. The principle of saving water is the same as that of saving energy. It is a positive national strategy with long-term strategic significance.

\section{HOW TO REALIZE THE VIRTUOUS CIRCLE OF WATER MANAGEMENT THROUGH SYSTEM INNOVATION}

The current water resources management system in China is based on the new "Water Law". The general pattern is that the Central Government has the leading group for water resources and soil and water conservation and the Ministry of Water Resources. The water resources department under the Ministry of Water Resources has seven river basin agencies and provincial-level water administrations. In the meantime, other relevant ministries and the Ministry of Water Resources of the Central Government cooperate with each other to coordinate the management of water resources in one area. For example, the Ministry of Land and Resources manages marine resources; the State Environmental Protection Administration collaboratively manages water pollution control and protection of water resources; the Ministry of Construction manages urban groundwater development and utilization, sewage treatment; the Ministry of Transportation manages inland navigation and waterway.

For example, at present, Shandong Province, water resources management is implemented "Water Law", which stipulates the "management of the basin and the management of the administrative area of the combination of management system." Shandong Province located in the Yellow River, Huaihe River and Haihe River three basins' crossing. The basin management agencies are mainly the Yellow River Conservancy Commission, the Huaihe River Conservancy Commission and the Hai River Conservancy Commission, which are responsible for the comprehensive planning of the Yellow River, Huaihe River and Haihe River Basin respectively, about water resources management, water 
resources protection and the formulation of flood control schemes.

Shandong Provincial Department of Water Resources is responsible for unified regional administration in Shandong Province. It has set up the Office of Water Resources, Department of Agricultural Water, Department of Soil and Water Conservation Department and the Office of Shandong Province Haihe River Basin Water Resources Management Authority, Shandong Province Huaihe River Basin Water Resources Management Bureau, Shandong Province Xiaoqing River Authority and other engineering administration.

The Third Plenary Session of the 18th CPC Central Committee made a comprehensive plan for deepening of the reform of the ecological civilization system, accelerating the establishment of an ecological civilization system, and improving the institutional mechanisms for the development of land and resources, conservation and utilization of resources, and protection of the ecological environment, and the promotion of water-rights trading system. General Secretary Xi Jinping put forward the water control ideas of "giving priority to water saving, space equalization, system control and making use of both hands", and carried out a comprehensive plan to promote the reform of water resources management system and mechanism and ensure the national water security. In the next step, it is pivotal to reform the water resources administrative examination and approval system and strictly enforce the responsibility and examination system of water resources management so as to continuously improve the water resources management system that integrates watershed management and regional management, etc. in order to change their functions, and constantly improve the government's regulatory capacity. Second, the measures should be taken to continue to innovate by accelerating the construction of a water-rights system, further improving the system of paid use of water resources, establishing and implementing a compensation system for aquatic ecosystems, and giving full play to the role of market mechanisms in water conservation and protection to enhance the market allocation of water resources. Thirdly, deepening the reform and constantly upgrade our urban and rural water management capabilities by deepening the reform of the water system, coordinating the equalization of water services in urban and rural areas, and strengthening departmental cooperation. Fourthly, it is necessary to strengthen the supervision and management of water functional areas by strengthening the rational allocation of water resources and scientific dispatch, further promoting the construction of aquatic ecological civilization, continuously guaranteeing people's livelihood and enhancing social service capacity. Only in this way can we rationalize the relations between the government and the market, the central government and local governments, fully mobilize all social forces to participate in the enthusiasm of water resources management, deepen the reform and innovation mechanism, and comprehensively enhance the ability and level of water resources management.

\section{CONCLUSION}

Water is the source of existence, the source of civilization and the foundation of ecology. On the basis of fully incorporating water resources management in the field of market economy management and attaching importance to the implementation of water saving guidelines, putting the water resources administrative examination and approval system, the combination of watershed management and regional management of water resources management system, water rights system etc. as the institutional innovation in all aspects, and further promoting the construction of aquatic ecological civilization, rationalizing the government and the market, the relationship between the central and local government to improve the overall management of water resources. Only by constantly following the laws and regulations, rationalizing and rebuilding the management system, and constantly innovating in management methods can we achieve a virtuous circle of water resources management and aquatic ecology.

\section{REFERENCES}

[1] Wu Dan.(2016). “Evolution of China's Economic Development and Utilization of Water Resources, Evaluation and Mechanism Analysis of "Decoupling" - A Comparative Study between China and the United States”. Journal of Hohai University, 01, pp.47-54. (In Chinese)

[2] Gao Lihong.(2013). “US Water Resources Management: Moving Forward with Challenges and Opportunities”. Modern Water Week.19 September 2013. (In Chinese)

[3] Sun Li.(2016). "UK public-private management of water resources”. People's Daily.26 March 2016. (In Chinese)

[4] Kou Huizhong.(2015). "French water resources and water environment information sharing management mode and its enlightenment”. Yellow River.6 July 2015. (In Chinese)

[5] Ma Zhiming.(2015). "Understanding and thinking of Australia's water resources”. Wuzhong Daily.17 November 2015. (In Chinese)

[6] Tong Guoqing.(2016). “Addressing water shortage: Is the Israeli model a new normal?”. China Water Resources.18 February 2016. (In Chinese)

[7] Ni Tao.(2014). "Water resources "emergency" restricts South Africa's economic development”. People's Daily.20 September 2014. (In Chinese)

[8] Zhang Liping, Xia Jun, Hu Zhifang.(2009). “Analysis of Water Resources Status and Water Resources Security in China”. RESOURCES AND ENVIRONMENT IN THE YANGTZE BASIN.02, pp.116-121. (In Chinese)

[9] Li Yuanyuan, Cao Jiating, Huang Huojian, Xing Ziqiang.(2018). "Advances in Integrated Management of Water Resources in China". Progress in Water Science.01, pp.1-13. (In Chinese)

[10] Włodzimierz Wojas, Sylwester Tyszewski.(2013). "Some examples comparing static and dynamic network approaches in water resources allocation models for the rivers of high instability of flows" .Journal of Water and Land Development.10, pp.21-27. 